\title{
Genetic diversity of Spanish fir (Abies pinsapo Boiss.) populations by means of megagametophyte storage proteins
}

\author{
María Angela MARTín*, Juan Bautista ALVAREZ, Luís Miguel MARTín \\ Departamento de Genética, Escuela Técnica Superior de Ingenieros Agrónomos y de Montes, Edificio Gregor Mendel, Campus de Rabanales, \\ Universidad de Córdoba, 14071 Córdoba, Spain
}

(Received 31 August 2009; accepted 8 January 2010)

Keywords:

endangered species /

genetic diversity /

megagametophyte storage protein /

Spanish fir

\begin{abstract}
- The Spanish fir (Abies pinsapo Boiss.) is a conifer endemic to southern Spain and belongs to a Mediterranean basin group of firs considered to be relict. Megagametophyte storage proteins are a useful tool for the evaluation of genetic variability due to the haploid nature of megagametophytes in conifers.

- In this paper, we report for the first time, the usefulness of megagametophyte storage proteins marker in A. pinsapo as a first investigation of the level of genetic diversity conserved in the extant stands of this relict conifer. For this, four populations were analysed from the three areas in which the species is still found. A total of thirty trees and ten megagametophytes per tree were analysed. In addition, 191 megagametophytes from two trees were assessed to identify polymorphic bands and to confirm Mendelian inheritance 1:1.

- Albumins have proved to be a good marker to assess the genetic variability in this species, due to their high level of variation. Fourteen polymorphic bands adjusted to the expected 1:1 segregation ratio, two cases of allelism and eight of linkage were detected.

- The genetic diversity study showed that, in the four populations, approximately half of the genetic diversity was among trees and the other half among seeds of each tree. Differentiation between populations was less than $6.0 \%$. Results from this study could be useful for determining appropriate conservation management strategies for this endangered species.
\end{abstract}

\section{INTRODUCTION}

The Spanish fir (Abies pinsapo Boiss.) is a conifer endemic to southern Spain and belongs to a Mediterranean basin group of firs, considered to be a relict species. In fact, it is an isolated fir because the nearest Abies populations are those of $A$. maroccana Trab. and A. tazaotana Villar in northern Morocco and A. alba Mill. in the Pyrenees.

The species is distributed in three isolated areas in "Sierra de Grazalema" Natural Park (N.P.) (Cadiz province) and "Sierra de las Nieves" N.P. and "Reales de Sierra Bermeja" Natural Reserve (N.R.) (Malaga province), declared protected zones. The most important stands are situated in "Sierra de las Nieves" N.P. with 2000 ha, followed by "Sierra de Grazalema" N.P. with 300 ha and "Reales de Sierra Bermeja" N.R. with 50 ha. In all the above areas A. pinsapo usually appears forming pure stands, although it is occasionally found with other tree species such as Quercus faginea Lam., Q. ilex L., Pinus

\footnotetext{
*Corresponding author: ge2macum@uco.es
}

halepensis Mill., P. pinaster Ait. and Juniperus oxycedrus L. (Arista and Talavera, 1997).

The Spanish fir forests represent one of the most unique ecosystems in the Iberian Peninsula due to their relict nature, and in order to ensure their conservation and protection, these sites have been declared "Biosphere Reserves" by UNESCO. However, there are several problems that affect the species as pests and diseases, low pollen production, climatic change and stand decay (Arista, 1995). Although there are some studies focused on the structure and dynamics of Spanish fir forests (Arista, 1995; Arista and Talavera, 1996; 1997), there appear to be no papers in the literature concerning the genetic structure of their populations. Specifically, most studies have been carried out to discriminate between the species of the Abies genus using different molecular markers as isozymes, mitochondrial DNA markers and chloroplast microsatellites (Pascual et al., 1993; Scaltsoyiannes et al., 1999; Terrab et al., 2007; Ziegenhagen et al., 2005).

A characteristic of gymnosperms that is useful for genetic studies is the haploid nature of megagametophyte. This tissue 
is derived from the female gametophyte that surrounds the embryo in a mature seed. Thus, analysis of the segregation pattern in parental trees may enable determination of the genetic control and linkage relationships without making crosses (El-Kassaby et al., 1987; Neale and Adams, 1981).

Genetic analysis of megagametophytes using isozymes has been carried out in conifers for the estimation of genetic diversity, heterozygosity, phylogeny and rate of gene flow in natural populations (Hamrick et al., 1992; Huang et al., 1994; Millar, 1983; Rogers, 1997; Wang and Liu, 1998; Wang and Nagasaka, 1997; Wheeler and Guries, 1982). Nevertheless, the role of seed storage proteins, that constitute an important component of the megagametophyte, has scarcely been studied. These proteins are, from a biological point of view, sources of amino acids for processes of synthesis occurring during germination. Nevertheless, the nature of these storage proteins is diverse, because different species can store these amino acids in four protein types (Gepts, 1990). In any case, their variations have no repercussion on any physiological function, which enables that these random changes to be maintained. Their main advantages as genetic markers are their high polymorphism, simple genetic control, environmental independence, and analysis efficiency.

Only few studies have been carried out on Gymnosperms megagametophyte storage proteins and in conifers they have mainly been based on biochemical characteristics of these proteins (Allona et al., 1994; Kurz et al., 1994; Piovesan et al., 1993). Likewise, our team used these proteins as markers to evaluate the genetic diversity of the stone pine ( $P$. pinea L.), revealing a high level of variation in the studied populations which suggested that this technique could be useful to assess the genetic diversity in conifers (Alvarez et al., 2004).

In this study, we report for the first time, the inheritance of megagametophyte storage proteins in A. pinsapo, together with the use of these proteins as genetic marker for assessing the genetic diversity conserved in the extant stands of the species.

\section{MATERIALS AND METHODS}

\subsection{Plant materials}

Four populations were selected from the only three areas where this species is distributed. Samples were taken from a total of thirty trees, varying in number from six to nine per population (Tab. I). The sampling sites and the number of trees per population were selected according to the area covered by the species in each site and the heterogeneity of the stands. Further, the trees selected were a minimum of $50 \mathrm{~m}$ apart to avoid the sampling of closely related trees.

At least three cones were collected per tree given the low fertility expected for this species. Indeed, the number of viable seeds did not exceed $10 \%$ of the total collected per tree. For the analysis, ten megagametophytes were used per tree. According to Morris and Spieth (1978), this is an optimum number of female megagametophytes per tree for estimating polymorphism in conifers.

\subsection{Protein extraction and electrophoretic analysis}

Megagametophytes were isolated by removing both the seed coat and the embryo. The lipids were removed with diethyl ether $\left(50: 1 \mathrm{v} / \mathrm{w}, 1 \mathrm{~h}, 4^{\circ} \mathrm{C}\right)$, followed by a second extraction with acetone $\left(50: 1 \mathrm{v} / \mathrm{w}, 1 \mathrm{~h}, 4^{\circ} \mathrm{C}\right)$. Albumin were extracted according the protocol proposed by Fonseca et al. (1997) for $Q$. suber $\mathrm{L}$. and modified by Alvarez et al. (2004) for P. pinea. $500 \mu \mathrm{L}$ of $10 \mathrm{mM}$ Tris- $\mathrm{HCl} \mathrm{pH}$ : $7.5+0.1 \%$ (w/v) dithiothreitol $+10 \mathrm{mM} \mathrm{MgCl}_{2}+10 \mathrm{mM} \mathrm{CaCl}_{2}$ were added to each sample and incubated for $2 \mathrm{~h}$ at $4{ }^{\circ} \mathrm{C}$. The samples were centrifuged at $14.000 \mathrm{~g}$ for $10 \mathrm{~min}$ and the supernatant containing the albumin fraction was transferred to a new tube. The samples were precipitated with $1 \mathrm{~mL}$ of cold-acetone, and the dried pellets were solubilised in buffer containing $625 \mathrm{mM}$ Tris- $\mathrm{HCl} \mathrm{pH}$ : $6.8,2 \%(\mathrm{w} / \mathrm{v})$ SDS, $10 \%(\mathrm{v} / \mathrm{v})$ glycerol, $0.02 \%(\mathrm{w} / \mathrm{v})$ bromophenol blue, and 2\% (w/v) dithiothreitol in ratio 1:5 (w/v).

Proteins were fractionated in vertical SDS-PAGE slabs in a discontinuous Tris-HCl-SDS buffer system (pH: 6.8/8.8) at a 12\% polyacrylamide concentration (w/v, C $=1.28 \%$ ). The Tris- $\mathrm{HCl} / \mathrm{glycine}$ buffer system of Laemmli (1970) was used. Electrophoresis was performed at a constant current of $30 \mathrm{~mA} / \mathrm{gel}$ at $18^{\circ} \mathrm{C}$ for $10 \mathrm{~min}$ after the tracking dye migrated off the gel. Gels were stained overnight with $12 \%(\mathrm{w} / \mathrm{v})$ trichloroacetic acid solution containing 5\% (v/v) ethanol and $0.05 \%(\mathrm{w} / \mathrm{v})$ Coomassie Brilliant Blue R-250. De-staining was carried out with tap water.

\subsection{Genetic analysis}

To confirm Mendelian inheritance of polymorphic bands, the offspring of two heterozygous trees were analysed. Segregation of all polymorphic bands was tested for goodness of fit to the expected 1:1 Mendelian segregation ratio using chi-square $\left(\chi^{2}\right)$ test. Similarly, linkage between bands was also tested. The linkage distance in cM was estimated by the recombination frequency $(r=f / n$, where $f$ is the number of recombinant types observed in $n$ megagametophytes).

The following genetic variability parameters were calculated in all the populations: number of alleles per locus $(A)$, percentage of polymorphic bands $(P)$, effective number of alleles per locus $\left(H_{e}\right)$ and expected heterozygosity $\left(H_{e}\right)$. The total genetic diversity over all populations $\left(H_{t}\right)$ and the average genetic diversities within $\left(H_{s}\right)$ and between $\left(D_{s t}\right)$ populations were also calculated according to Nei (1973). The relative magnitude of genetic differentiation between populations, $G_{s t}$, was estimated as $D_{s t} / H_{t}$. Popgene software version 1.32 (Yeh et al., 1997) was used for the estimation of the above parameters.

The genetic identity $(I)$ values were estimated between populations (Nei, 1972). To visualize the genetic relationship among populations, a dendrogram was constructed based on Nei's genetic distances $(D=-\ln I)$ by an unweighted pair-group method of cluster analysis using arithmetic averages (UPGMA) (Sneath and Sokal, 1973). The significance of the phenogram was tested by cophenetic correlation coefficient (Rohlf and Fisher, 1986).

\section{RESULTS}

\subsection{Albumin differentiation}

The sequential extraction process resulted in four possible protein fractions: albumins, globulins, prolamins and glutelins. 
Table I. Description of the four populations of Abies pinsapo evaluated.

\begin{tabular}{|c|c|c|c|c|c|c|}
\hline Population & No. trees & Province & Location & $\begin{array}{c}\text { Latitude } \\
(\mathrm{N})\end{array}$ & $\begin{array}{l}\text { Longitude } \\
\text { (W) }\end{array}$ & $\begin{array}{l}\text { Altitude } \\
\text { (m a.s.l.) }\end{array}$ \\
\hline $\mathrm{SN}-2$ & 9 & Malaga & N.P. Sierra de las Nieves & $36^{\circ} 43^{\prime} 48^{\prime \prime}$ & $4^{\circ} 58^{\prime} 23^{\prime \prime}$ & 1130 \\
\hline SG-1 & 6 & Cadiz & N.P. Sierra de Grazalema & $36^{\circ} 46^{\prime} 31^{\prime \prime}$ & $5^{\circ} 25^{\prime} 43^{\prime \prime}$ & 1000 \\
\hline
\end{tabular}
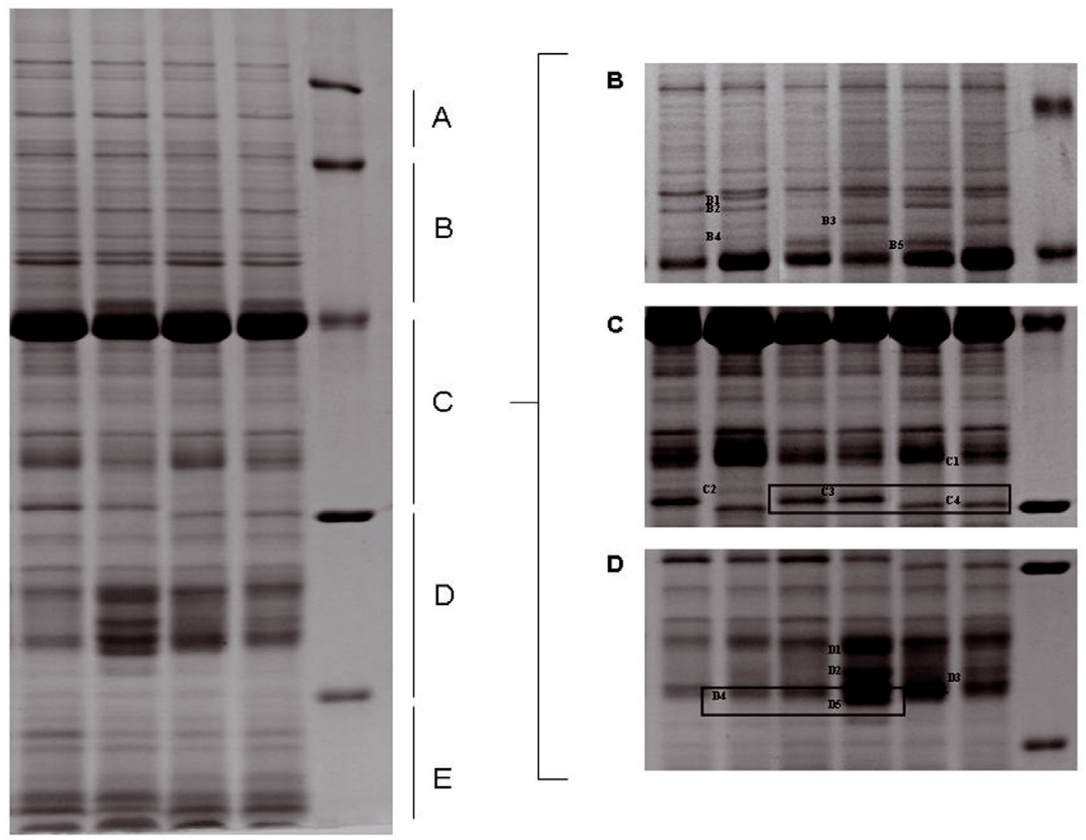

Figure 1. SDS-PAGE of representative samples of the variation found in A. pinsapo. B1-D5 are the polymorphic bands found in the study. In square are shown the two allelism cases, C3 vs. C4 and D4 vs. D5.

Albumin was the fraction which showed the highest and the clearest resolution between bands with absence of ghost bands and other artefacts. Moreover, these bands were consistent, being the procedure higher repetitive.

According to the molecular weight marker used as reference, five zones were recorded in the gel (Fig. 1), classified as A (upper $66 \mathrm{KDa}), \mathrm{B}$ (66-45 KDa), C (45-30 KDa), $\mathrm{D}(30-14 \mathrm{KDa})$ and $\mathrm{E}$ (below $14 \mathrm{KDa})$. In total, up to 41 different bands were consistently scored, 14 of which were polymorphic (34\%). No polymorphic bands were detected in zones $\mathrm{A}$ and $\mathrm{E}$, whereas in the three others (zones B, C and D), five, four and five polymorphic bands were identified respectively (Fig. 1). The bands were named by the letter corresponding to the zone where they were situated and a corresponding number as a function of their mobility (Fig. 1).

The presence or absence of each polymorphic band was fit to a 1:1 ratio, and no significant deviation from the expected segregation was detected in any case (Tab. II). Of the 48 possible pairs of band combinations two allelic relationships were detected between C3 vs. C4 and D4 vs. D5 (Tab. II). In fact, in both cases each seed displayed either one or other of the two bands, but no simultaneous presence or absence was detected in any case (Fig. 1). Further, 38 cases of independence
Table II. Observed segregation of albumins in two trees. Chi-square test and goodness of fit to the 1:1 ratio.

\begin{tabular}{|c|c|c|c|c|c|c|}
\hline & & $\begin{array}{l}\text { Tree } 1 \\
I=95)\end{array}$ & & & $\begin{array}{l}\text { ree } 2 \\
=96)\end{array}$ & \\
\hline$\overline{\text { Band }}$ & $\begin{array}{c}\text { Segregation } \\
(\mathrm{P} / \mathrm{A})\end{array}$ & $\begin{array}{c}\chi^{2} \\
(\mathrm{~d} f=1)\end{array}$ & $p$ & $\begin{array}{c}\text { Segregation } \\
(\mathrm{P} / \mathrm{A})\end{array}$ & $\begin{array}{c}\chi^{2} \\
(\mathrm{~d} f=1)\end{array}$ & $p$ \\
\hline$\overline{\mathrm{B} 1}$ & $95 / 0$ & - & - & $45 / 51$ & 0.375 & 0.540 \\
\hline B2 & $95 / 0$ & - & - & $96 / 0$ & - & - \\
\hline B3 & $95 / 0$ & - & - & $48 / 48$ & 0.000 & 1.000 \\
\hline B4 & $95 / 0$ & - & - & $96 / 0$ & - & - \\
\hline B5 & $51 / 44$ & 0.516 & 0.473 & $45 / 51$ & 0.375 & 0.540 \\
\hline $\mathrm{C} 1$ & $49 / 46$ & 0.095 & 0.758 & $96 / 0$ & - & - \\
\hline $\mathrm{C} 2$ & $44 / 51$ & 0.516 & 0.473 & $96 / 0$ & - & - \\
\hline C3 & $53 / 42$ & 1.274 & 0.259 & $0 / 96$ & - & - \\
\hline $\mathrm{C} 4$ & $42 / 53$ & 1.274 & 0.259 & $96 / 0$ & - & - \\
\hline D1 & $47 / 48$ & 0.011 & 0.918 & 0/96 & - & - \\
\hline D2 & $46 / 49$ & 0.095 & 0.758 & $0 / 96$ & - & - \\
\hline D3 & $44 / 51$ & 0.516 & 0.473 & $0 / 96$ & - & - \\
\hline D4 & $52 / 43$ & 0.853 & 0.356 & $96 / 0$ & - & - \\
\hline D5 & $43 / 52$ & 0.853 & 0.356 & $0 / 96$ & - & - \\
\hline
\end{tabular}

$\mathrm{P}$, presence of the band. A, absence of the band. Bands C3/C4 and D4/D5 were allelic. 
Table III. Observed segregation using pairs of bands. Chi-square test, goodness of fit to the independence 1:1:1:1 ratio.

\begin{tabular}{|c|c|c|c|c|c|c|c|}
\hline Tree & Bands & P1 & $\mathrm{P} 2$ & P1P2 & A1A2 & $\chi^{2}(\mathrm{~d} f=3)$ & $p$ \\
\hline Tree 1 & $\mathrm{~B} 5 / \mathrm{C} 2$ & 32 & 25 & 19 & 19 & 4.83 & 0.185 \\
\hline \multirow[t]{34}{*}{$(N=95)$} & $\mathrm{B} 5 / \mathrm{C} 3$ & 19 & 21 & 32 & 23 & 4.16 & 0.245 \\
\hline & $\mathrm{B} 5 / \mathrm{C} 4$ & 31 & 22 & 20 & 22 & 3.06 & 0.382 \\
\hline & $\mathrm{B} 5 / \mathrm{D} 2$ & 28 & 23 & 23 & 21 & 1.13 & 0.771 \\
\hline & B5/D4 & 19 & 20 & 32 & 24 & 4.41 & 0.220 \\
\hline & B5/D5 & 32 & 24 & 19 & 20 & 4.41 & 0.220 \\
\hline & $\mathrm{C} 1 / \mathrm{C} 3$ & 18 & 22 & 31 & 24 & 3.74 & 0.291 \\
\hline & $\mathrm{C} 1 / \mathrm{C} 4$ & 28 & 21 & 21 & 25 & 1.46 & 0.691 \\
\hline & $\mathrm{C} 1 / \mathrm{D} 2$ & 25 & 22 & 24 & 24 & 0.20 & 0.978 \\
\hline & $\mathrm{C} 1 / \mathrm{D} 3$ & 23 & 18 & 26 & 28 & 2.39 & 0.496 \\
\hline & $\mathrm{C} 1 / \mathrm{D} 4$ & 21 & 24 & 28 & 22 & 1.21 & 0.750 \\
\hline & $\mathrm{C} 1 / \mathrm{D} 5$ & 28 & 22 & 21 & 24 & 1.21 & 0.750 \\
\hline & $\mathrm{C} 2 / \mathrm{D} 1$ & 18 & 21 & 26 & 30 & 3.57 & 0.312 \\
\hline & $\mathrm{C} 2 / \mathrm{D} 2$ & 22 & 24 & 22 & 27 & 0.71 & 0.872 \\
\hline & C2/D3 & 21 & 21 & 23 & 30 & 2.31 & 0.512 \\
\hline & $\mathrm{C} 2 / \mathrm{D} 4$ & 23 & 31 & 21 & 20 & 3.15 & 0.369 \\
\hline & $\mathrm{C} 2 / \mathrm{D} 5$ & 21 & 20 & 23 & 31 & 3.15 & 0.369 \\
\hline & C3/D1 & 31 & 25 & 22 & 17 & 4.33 & 0.228 \\
\hline & $\mathrm{C} 3 / \mathrm{D} 2$ & 26 & 19 & 27 & 23 & 1.63 & 0.652 \\
\hline & C3/D3 & 31 & 22 & 22 & 20 & 3.06 & 0.382 \\
\hline & $\mathrm{C} 3 / \mathrm{D} 4$ & 21 & 20 & 32 & 22 & 3.91 & 0.272 \\
\hline & C3/D5 & 32 & 22 & 21 & 20 & 3.91 & 0.272 \\
\hline & C4/D1 & 17 & 22 & 25 & 31 & 4.33 & 0.228 \\
\hline & $\mathrm{C} 4 / \mathrm{D} 2$ & 23 & 27 & 19 & 26 & 1.63 & 0.652 \\
\hline & C4/D3 & 20 & 22 & 22 & 31 & 3.06 & 0.382 \\
\hline & $\mathrm{C} 4 / \mathrm{D} 4$ & 22 & 32 & 20 & 21 & 3.91 & 0.272 \\
\hline & C4/D5 & 20 & 21 & 22 & 32 & 3.91 & 0.272 \\
\hline & D1/D2 & 27 & 26 & 20 & 22 & 1.38 & 0.710 \\
\hline & D1/D4 & 26 & 31 & 21 & 17 & 4.66 & 0.198 \\
\hline & D1/D5 & 21 & 16 & 26 & 32 & 5.93 & 0.115 \\
\hline & D2/D3 & 20 & 26 & 18 & 31 & 4.41 & 0.220 \\
\hline & D2/D4 & 21 & 27 & 25 & 22 & 0.96 & 0.811 \\
\hline & D2/D5 & 25 & 22 & 21 & 27 & 0.96 & 0.811 \\
\hline & D3/D4 & 25 & 33 & 19 & 18 & 6.01 & 0.111 \\
\hline & D3/D5 & 19 & 18 & 25 & 33 & 6.01 & 0.111 \\
\hline \multirow{3}{*}{$\begin{array}{l}\text { Tree } 2 \\
(N=96)\end{array}$} & B1/B3 & 18 & 21 & 27 & 30 & 3.80 & 0.284 \\
\hline & $\mathrm{B} 1 / \mathrm{B} 5$ & 20 & 23 & 25 & 28 & 1.44 & 0.696 \\
\hline & B3/B5 & 24 & 21 & 24 & 27 & 0.77 & 0.857 \\
\hline
\end{tabular}

$\mathrm{P}$, presence of the band. A, absence of the band.

(fit a 1:1:1:1 segregation ratio) (Tab. III) and 8 cases of linkage were detected (Tab. IV).

At population level, from all the studied samples, the bands that showed the highest frequencies were B3, C4 and D4, appearing in more than $78 \%$ of cases. The bands with the lowest frequencies, all situated in zone D (D3, D5 and D2, respectively), were present in less than $17 \%$ of the individuals (Tab. V). In general, bands displayed a wide distribution among the populations. The identified polymorphic bands
Table IV. Observed segregation using pairs of bands. Chi-square test, goodness of fit to the 1:1:1:1 ratio and linkage distance $(d)$.

\begin{tabular}{lccccccc}
\hline $\begin{array}{l}\text { Bands } \\
(N=95)\end{array}$ & $\mathrm{P} 1$ & $\mathrm{P} 2$ & $\mathrm{P} 1 \mathrm{P} 2$ & $\mathrm{~A} 1 \mathrm{~A} 2$ & $\begin{array}{c}\chi^{2} \\
(\mathrm{~d} f=3)\end{array}$ & $p$ & $\begin{array}{c}d \\
(\mathrm{cM})\end{array}$ \\
\hline $\mathrm{B} 5 / \mathrm{C} 1$ & 11 & 10 & 39 & 35 & 29.93 & 0.000 & $22.1 \mathrm{c}$ \\
$\mathrm{B} 5 / \mathrm{D} 1$ & 18 & 14 & 33 & 30 & 10.64 & 0.014 & $33.7 \mathrm{c}$ \\
$\mathrm{B} 5 / \mathrm{D} 3$ & 19 & 12 & 32 & 32 & 12.49 & 0.006 & $32.6 \mathrm{c}$ \\
$\mathrm{C} 1 / \mathrm{C} 2$ & 34 & 29 & 15 & 17 & 10.73 & 0.013 & $33.7 \mathrm{r}$ \\
$\mathrm{C} 1 / \mathrm{D} 1$ & 17 & 15 & 32 & 31 & 10.22 & 0.017 & $33.7 \mathrm{c}$ \\
$\mathrm{C} 2 / \mathrm{C} 3$ & 35 & 44 & 9 & 7 & 43.56 & 0.000 & $16.8 \mathrm{r}$ \\
$\mathrm{C} 2 / \mathrm{C} 4$ & 9 & 7 & 35 & 44 & 43.56 & 0.000 & $16.8 \mathrm{c}$ \\
$\mathrm{D} 1 / \mathrm{D} 3$ & 17 & 14 & 30 & 34 & 11.98 & 0.007 & $32.6 \mathrm{c}$ \\
\hline
\end{tabular}

$\mathrm{P}$, presence of the band; A, absence of the band; c, coupling linkage phase; $\mathrm{r}$, repulsion linkage phase.

were present in all populations, except band $\mathrm{C} 4$ that was monomorphic in the SG-1 population (Tab. V).

\subsection{Variation within and between populations}

All populations showed high polymorphism for the assessed bands. Populations SN-1, SN-2 and RSB-1 had the highest levels of polymorphic loci while this value was the lowest in population SG-1, where band $\mathrm{C} 4$ was monomorphic (Tab. VI). The mean expected heterozygosity $\left(H_{e}\right)$ was 0.379 , ranging from $H_{e}=0.412$ for the $\mathrm{SN}-2$ population and $H_{e}=$ 0.322 in RSB-1 (Tab. VI).

In the four populations, approximately half of the genetic diversity was among trees within populations and the other half among seeds within trees (Tab. VII). The total genetic diversity $\left(H_{t}\right)$ in the evaluated populations was 0.377 , which was divided into two components, $H_{s}$ and $D_{s t}$, to assess the genetic diversity within and between populations. The total genetic differentiation among populations $\left(G_{s t}\right)$ was $5.8 \%$, which indicates that $94.2 \%$ of the variation was within populations. Further, the highest differentiation among population pairs was found with RSB-1 and SG-1 $\left(G_{s t}=7.0 \%\right)$ whereas the two populations from "Sierra de las Nieves" N.P. showed the lowest value $\left(G_{s t}=1.2 \%\right)$ (Tab. VII).

\subsection{Genetic distances}

Genetic identity coefficients $(I)$ were estimated for paired comparisons of all four populations based on the normalized identity of all polymorphic bands between each pair of populations. The mean value was $I=0.943$, ranging from $I=0.926$ for the pair SG-1/RSB-1 to $I=0.986$ for SN-1/SN-2.

A dendrogram, based on Nei's genetic distance matrix, was tested for the significance of the clustering method. The cophenetic correlation coefficient $(r=0.852 * * *)$ indicated a good fit between the cluster and the data. Cluster analysis based on genetic distances, revealed that populations displayed a pattern of geographical variation among them (Fig. 2). 
Table V. Frequencies of each band in the 297 seeds analysed and in the 4 populations evaluated.

\begin{tabular}{|c|c|c|c|c|c|c|c|}
\hline \multirow[b]{2}{*}{ Zone } & \multicolumn{3}{|c|}{ Seeds $(n=297)$} & \multicolumn{4}{|c|}{ Populations(\%) } \\
\hline & Band & $N$ & $\%$ & $\mathrm{SN}-1(n=69)$ & $\mathrm{SN}-2(n=90)$ & RSB-1 $(n=78)$ & SG-1 $(n=60)$ \\
\hline \multirow[t]{5}{*}{$\mathrm{B}$} & B1 & 134 & 45.1 & 59.4 & 52.2 & 35.9 & 30.0 \\
\hline & B2 & 128 & 43.1 & 37.7 & 54.4 & 32.1 & 45.0 \\
\hline & B3 & 258 & 86.9 & 92.8 & 87.8 & 88.5 & 75.0 \\
\hline & B4 & 206 & 69.4 & 71.0 & 66.7 & 85.9 & 48.3 \\
\hline & B5 & 224 & 75.4 & 81.2 & 68.9 & 78.2 & 73.3 \\
\hline & $\mathrm{C} 2$ & 210 & 70.7 & 85.5 & 67.8 & 75.6 & 50.0 \\
\hline & $\mathrm{C} 3$ & 95 & 32.0 & 36.2 & 43.3 & 33.3 & 6.7 \\
\hline & $\mathrm{C} 4$ & 233 & 78.5 & 76.8 & 75.6 & 66.7 & 100.0 \\
\hline \multirow[t]{2}{*}{$\bar{D}$} & D1 & 151 & 50.8 & 33.3 & 46.7 & 82.1 & 35.0 \\
\hline & D2 & 50 & 16.8 & 24.6 & 23.3 & 5.1 & 13.3 \\
\hline
\end{tabular}

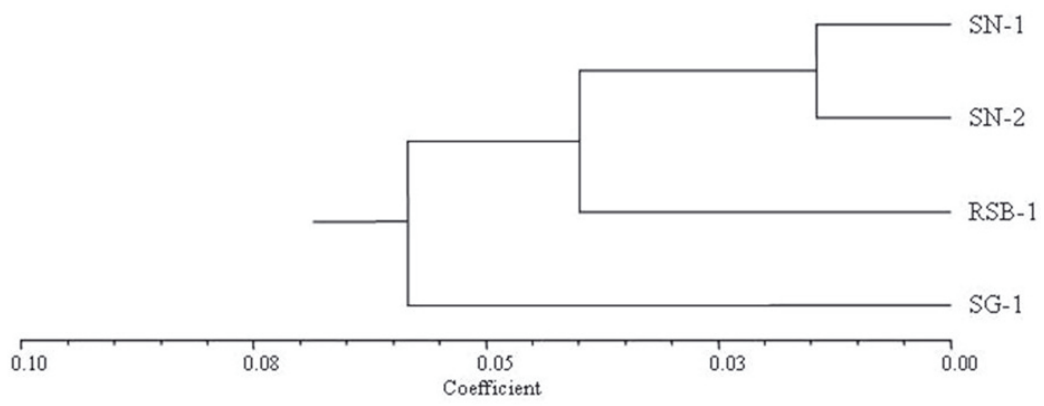

Figure 2. Dendrogram of $A$. pinsapo populations based on Nei's genetic distance. (Co-phenetic correlation $=0.852 * * *)$.

Table VI. Albumin genetic diversity based on the 14 polymorphic bands identified in the four Spanish fir populations.

\begin{tabular}{lccccc}
\hline Population & Size & $A$ & $N_{e}$ & $P(\%)$ & $H_{e}(\mathrm{se})$ \\
\hline SN-1 & 7 & 2.00 & 1.57 & 100.0 & $0.348(0.10)$ \\
SN-2 & 9 & 2.00 & 1.73 & 100.0 & $0.412(0.08)$ \\
RSB-1 & 8 & 2.00 & 1.51 & 100.0 & $0.322(0.11)$ \\
SG-1 & 6 & 1.93 & 1.59 & 92.9 & $0.338(0.07)$ \\
\hline Overall & & 2.00 & 1.65 & 100.0 & $0.379(0.09)$ \\
\hline
\end{tabular}

$A=$ number of alleles per locus; $N_{e}=$ effective number of alleles; $P=$ percentage polymorphic bands; $H_{e}=$ expected heterozygosity. se, standard error.

\section{DISCUSSION}

Our data indicate that albumin was the most appropriate fraction to assess genetic diversity in A. pinsapo, due to the high polymorphism, consistent repeatability and simple genetic control. Nevertheless, this result contrasts with that obtained by other authors that indicate the globulin as the best fraction for genetic analysis in other conifers (Allona et al., 1994; Alvarez et al., 2004).
The segregation analysis of megagametophytes demonstrated the genetic control in polymorphic bands, indicating that they exhibit Mendelian inheritance. This result agrees with that obtained by Pascual et al. (1993) using isozymes in A. pinsapo. This being the first study of inheritance of these proteins, the two cases of allelism and the eight cases of linkage, constitute the beginning of the cataloguing of seed storage protein alleles in this species. As well as these two loci (allelic bands), ten more loci were detected, the majority being independent. This high percentage of independent loci provides more efficient and accurate estimates for some population analysis such as genetic distance and matting systems (Nei, 1975; Shaw and Allard, 1981).

According to the results obtained for albumins, the number of polymorphic bands was $34.0 \%$. The bands were very variable with a mean of polymorphic loci of $98.2 \%$. This value was significantly higher than that found in the same species using isozymes (12.5\%, Scaltsoyiannes et al. 1999) and similar to that detected in P. pinea (97.0\%, Alvarez et al., 2004).

The mean genetic diversity $\left(H_{e}=0.379\right)$ was higher than the detected in the same species $\left(H_{e}=0.010\right)$ using isozymes (Scaltsoyiannes et al., 1999) but significantly lower than that found by Terrab et al. (2007) using chloroplast microsatellites 
Table VII. Differentiation of albumin diversity within and between 4 Spanish fir populations, and comparison between pairs of populations.

\begin{tabular}{|c|c|c|c|c|c|}
\hline Populations & $N$ & $H_{t}$ & $H_{s}$ & $D_{s t}$ & $G_{s t}(\%)$ \\
\hline SN-1 & 7 & 0.343 & 0.192 & 0.151 & 44.1 \\
\hline $\mathrm{SN}-2$ & 9 & 0.412 & 0.208 & 0.204 & 49.4 \\
\hline RSB-1 & 8 & 0.321 & 0.157 & 0.164 & 51.2 \\
\hline SG-1 & 6 & 0.338 & 0.164 & 0.174 & 51.4 \\
\hline Average species level & 4 & 0.377 & 0.355 & 0.022 & 5.8 \\
\hline \multicolumn{6}{|c|}{ Comparison among populations } \\
\hline SN-1 vs. SN-2 & & 0.385 & 0.380 & 0.005 & 1.2 \\
\hline SN-1 vs. RSB-1 & & 0.349 & 0.335 & 0.014 & 4.0 \\
\hline SN-1 vs. SG-1 & & 0.367 & 0.343 & 0.024 & 4.8 \\
\hline SN-2 vs. RSB-1 & & 0.379 & 0.367 & 0.012 & 3.2 \\
\hline SN-2 vs. SG-1 & & 0.389 & 0.375 & 0.014 & 3.6 \\
\hline RSB-1 vs. SG-1 & & 0.355 & 0.330 & 0.025 & 7.0 \\
\hline
\end{tabular}

$H_{t}=$ total gene diversity; $H_{s}=$ average gene diversity within populations; $D_{s t}=$ average gene diversity between populations; $G_{s t}=$ gene diversity between populations, relative to $H_{t}$.

$\left(H_{e}=0.833\right)$. Moreover, this value was higher than that reported for other species of the genus Abies as A. alba (0.149), A. cephalonica $\left(H_{e}=0.161\right)$ and $A$. nephrolepis $(0.240)$ or found in other conifers $\left(H_{e}=0.173\right.$; Hamrick and Godt, 1990; Woo et al., 2008). However, most of the available population genetic data in the species are based on other markers, which may be the reason why the values are not comparable with our results.

In general, widely distributed Abies species have higher values of genetic diversity and lower levels of genetic differentiation than species with restricted distribution (Diebel and Feret, 1991; Fady and Conkle, 1993). Conversely, genetic differentiation detected among populations $\left(G_{s t}=5.8 \%\right)$ was lower than the average value for gymnosperm $\left(G_{s t}=18 \%\right)$ and woody species with an endemic distribution $\left(G_{s t}=14.1 \%\right.$; Hamrick et al., 1992). The results agree with Terrab et al. (2007) who found a low differentiation among populations of the species $\left(F_{s t}=0.04\right)$. This low value seems to be typical for out-crossing wind-pollinated species (Hamrik, 1989) and could indicate that gene flow through pollen among populations is fairly high and there are no strong barriers to gene exchange. In fact, the populations examined in the study are from a restricted area in southern Spain, separated by only a few kilometres. Indeed, the two populations from the same site (Sierra de las Nieves), were much more similar to each other than they were to the other populations, even though this area represents $85 \%$ of the whole area covered by this relict species.

In conclusion, albumins have been shown to be a good marker of the genetic diversity in A. pinsapo due to their high polymorphism, neutrality, consistent repeatability and simple genetic control. The preliminary analysis has highlighted a considerable genetic diversity in the species and low differentiation between populations. Moreover, the results suggest that increasing the number of locations could give interesting additional information on the spatial distribution of the genetic diversity in this species. Accordingly, the study of trees of different ages within locations would be very useful to determine the evolution between these populations and the increase or decrease in the genetic diversity as a consequence of the process of inbreeding. This knowledge could add complementary information to that currently available and thereby play a significant role in the formulation of appropriate conservation management strategies for the species.

Acknowledgements: The authors thank J. Lopez Quintanilla (Natural Park of "Sierra de las Nieves", Malaga, Spain) for the supply of the seeds of Spanish fir.

\section{REFERENCES}

Allona I., Collada C., Casado R., and Aragoncillo C., 1994. Electrophoretic analysis of seed storage proteins from gymnosperms. Electrophoresis 15: 1062-1067.

Alvarez J.B., Toledo M.J., Abellanas B., and Martín L.M., 2004. Use of megagametophyte storage proteins as markers of the genetic diversity in stone pine (Pinus pinea L) in Andalusia, Spain. Genet. Resour. Crop Evol. 51: 621-627.

Arista M., 1995. The structure and dynamics of an Abies pinsapo forest in southern Spain. For. Ecol. Manage. 74: 81-89.

Arista M. and Talavera S., 1996. Density effect on the fruit-set, seed crop viability and seedling vigour of Abies pinsapo. Ann. Bot. 77: 187189.

Arista M. and Talavera S., 1997. Gender expression in Abies pinsapo Boiss., a Mediterranean fir. Ann. Bot. 79: 337-342.

Diebel K.E. and Feret P.P., 1991. Isozyme variation within the Fraser fir (Abies fraseri (Pursh) Poir.) population on Mount Rogers, Virginia: Lack of microgeographic differentiation. Silvae Genet. 40: 79-85.

El-Kassaby Y.A., Meagher M.D., Parkinson J., and Portlock F.T., 1987. Allozyme inheritance, heterozygosity and outcrossing rate among Pinus monticola near Ladysmith, British Columbia. Heredity 58: 173-181.

Fady B. and Conckle M.T., 1993. Allozyme and possible phylogenetic implications in Abies cephalonica Loudon and some related eastern Mediterranean firs. Silvae Genet. 42: 351-359.

Fonseca P.A., Ferreira R.B., and Texeira A.R., 1997. Seed proteins from Quercus suber. J. Agric. Food Chem. 45: 3443-3447. 
Gepts P., 1990. Genetic diversity of seed storage proteins in plants. In: Brown A.H.D., Clegg M.T., Kahler A.L., and Weir B.S. (Eds.), Plant population genetics, breeding and genetic resources. Sinauer Associates Inc Publishers, Suderland, Massachusetts, pp. 64-82.

Hamrick J.L., 1989. Isozymnes and the analysis of genetic structure in plant populations. In: Soltis D.E., and Soltis P.S. (Eds.), Isozymes in plant biology, Portland, Oregon, pp. 87-105.

Hamrick J.L. and Godt M.J.W., 1990. Allozyme diversity in plant species. In: Brown H.D., Clegg M.T., Khaler A.L., and Weir B.S. (Eds.), Plant Population Genetics, Breeding, and Genetic Resources. Sinauer Press, Sunderland, MA, pp. 43-63.

Hamrick J.L., Godt M.J.W., and Sherman-Broyles S.L., 1992. Factors influencing levels of genetic diversity in woody plant species. New For. 6: $95-124$.

Huang Q.Q., Tomaru N., Wang L.H., and Ohba K., 1994. Genetic-control of isozyme variation in masson pine, Pinus massoniana Lamb. Silvae Genet. 43: 285-292.

Kurz M.L., Roberts D.R., Flinn B.S., and Vidaver W.E., 1994. A morphological and biochemical analysis of embryo maturation during yellow cypress seed development. Can. J. For. Res. 24: 431-441.

Laemmli U.K., 1970. Cleavage of structural proteins during the assembly of the head of bacteriophage T4. Nature 227: 680-685.

Millar C.I., 1983. A steep cline in Pinus muricata. Evolution 37: $311-$ 319.

Morris R.W. and Spieth P.T., 1978. Sampling strategies for using female gametophytes to estimate heterozygosity in conifers. Theor. Appl. Genet. 51: 217-222.

Neale D. and Adams W.T., 1981. Inheritance of isozyme variants in seed tissues of balsam fir (Abies balsamea). Can. J. Bot. 59: 1285-1291.

Nei M., 1972. Genetic distances between different populations. Am. Nat. 106: 283-292.

Nei M., 1973. Analysis of gene diversity in subdivided populations. Proc. Natl. Acad. Sci. USA 70: 3321-3323.

Nei M., 1975. Molecular population genetics and evolution. Amsterdam, North-Holland.

Pascual L., Garcia F.J., and Perfectti F., 1993. Inheritance of isozyme variation in seed tissues of Abies pinsapo Boiss. Silvae Genet. 42: 335-340.

Piovesan G., Pelosi C., Schirone A., and Schirone B., 1993. Taxonomic evaluations of the genus Pinus (Pinaceae) based on electrophoretic data of salt soluble and insoluble seed storage proteins. Plant. Syst. Evol. 186: 57-68.

Rogers D.L., 1997. Inheritance of allozymes from seed tissues of the hexaploid gymnosperm, Sequoia sempervirens (D. Don) Endl (Coast redwood). Heredity 78: 166-175.

Rohlf F.J. and Fisher D.L., 1986. Test for hierarchical structure in random data sets. Syst. Zool. 17: 407-412.

Scaltsoyiannes A., Tsaktsira M., and Drouzas A.D., 1999. Allozyme differentiation in the Mediterranean firs (Abies, Pinaceae). A first comparative study with phylogenetic implications. Plant Syst. Evol. 216: 289-307.

Shaw D.V. and Allard R.W., 1981. Analysis of mating system parameters and population structure in Douglas Fir using single-locus and multi-locus methods. In: Conkle M.T., and Berkeley C.A. (Eds.), Proc. Symp. Isozymes North Am. Forest Trees and Forest Insects, USDA Forest Serv. Gen. Techn. Rep. PSW-48, pp. 18-22.

Sneath P.H.A. and Sokal R.R., 1973. Numerical Taxonomy. San Francisco, Freedman.

Terrab A., Talavera S., Arista M., Paun O., Stuessy T.F., and Tremetsberger K., 2007. Genetic diversity at chloroplast microsatellites (cpSSR) and geographic structure in endangered West mediterranean firs (Abies spp., Pinaceae). Taxon 56: 409-416.

Wang C.T. and Liu T.P., 1998. Inheritance and linkage relationships of allozymes, and estimation of outcrossing rates in a seed orchard of Cunninghamia konishii Hay. Silvae Genet. 47: 33-37.

Wang Z.M. and Nagasaka K., 1997. Allozyme variation in natural populations of Picea glehnii in Hokkaido, Japan. Heredity 78: 470-475.

Wheeler N.C. and Guries R.P., 1982. Population structure, genetic diversity, and morphological variation in Pinus contorta Dougl. Can. J. For. Res. 12: 595-606.

Woo L.S., Hoon Y.B., Don H.S., Ho S.J., and Joo L.J., 2008. Ann. For. Sci. 65: 302-308.

Yeh F.C., Yang R.C., Boyle T.B.J., Ye Z.H., and Mao J.X., 1997. Popgene ver 1.32 . The user-friendly software for population genetic analysis. Molecular Biology and Biotechnology Center, University of Alberta, Canada.

Ziegenhagen B., Fady B., Kuhlenkamp V., and Liepelt S., 2005. Differentiating groups of Abies species with a simple molecular marker. Silvae Genet 54: 123-126. 